carried out many of the cyst punctures. P. A. T. acknowledges the financial assistance of the Cancer Research Campaign.

\author{
References \\ ${ }^{1}$ King, M. C., Friedenberg, R. M., and Tena, L. B., Radiology, 1968, 91, \\ 217. \\ 2 Felson, B., and Moskowitz, M., American fournal of Roentgenology, 1969, \\ 107,720 . \\ ${ }^{3}$ Sherwood, T., and Stevenson, J. J., Clinical Radiology, 1971, 22, 180. \\ 4 Stevenson, J. J., and Sherwood, T., British fournal of Urology, 1971, 43, \\ 646. \\ ${ }^{5}$ Bosniak, M. A., personal communication. \\ ${ }^{6}$ Folin, J., Acta Radiologica, suppl., 267, p. 7.
}

${ }^{7}$ Meaney, T. F., Radiology, 1969, 93, 361.

${ }^{8}$ King, D. L., Radiology, 1972, 105, 633.

${ }^{9}$ Leopold, G. R., et al., Radiology, 1973, 109, 671.

${ }_{10}$ Pollack, H. M., Goldberg, B. B., and Bogash, M., fournal of Urology, 1974, 111, 326.

11 Barnett, E., and Morley, P., British Medical Bulletin, 1972, 28, 196.

12 Hately, W., and Whitaker, R. H., British fournal of Urology, 1973, 45, 468.

13 Jeans, W. D., Penry, J. B., and Roylance, J., Clinical Radiology, 1972, 23, 298

14 von Schreeb, T., et al., Scandinavian fournal of Urology and Nephrology, $1967,1,270$

15 Emmett, J. L., Levine, S. R., and Woolner, L. B., British fournal of Urology, 1963, 35, 403.

16 Lang, E. K., Radiology, 1971, 101, 7.

17 Thornbury, J. R., Radiology, 1972, 105, 299.

18 Jackman, R. J., and Stevens, G. M., Radiology, 1974, 110, 7.

\title{
Regular Short Haemodialysis in End-stage Renal Failure
}

\author{
A. M. MARTIN, \\ A. ODURO-DOMINAH, \\ J. K. GIBBINS, \\ D. DEVAPAL, \\ D. C. MITCHELL
}

British Medical fournal, 1975, 3, 758-759

\section{Summary}

A study was made of thrice weekly haemodialysis of 3-31 hours' duration using a large surface area dialyser in patients with end-stage renal failure. Body water, potassium, and blood pressure control were satisfactory and comparable with the more widely used long dialysis schedules (6-9 hours thrice weekly). Patient rehabilitation was improved overall and the regimen enabled the dialysis unit to treat more patients despite a reduction in technical and nursing staff. The technique proved inadequate, however, in two patients with an intercurrent infection, and more intensive dialysis is recommended in such cases.

\section{Introduction}

In the United Kingdom there are probably about 50 patients per million population annually with end-stage renal failure who are suitable for dialysis or renal transplantation. ${ }^{1}$ Most patients are treated in chronically overworked hospital centres. Many do not receive treatment because of lack of dialysis unit space and insufficient trained nursing and technical personnel. Shorter dialysis times would intensify the use of renal units. Several authors have shown that this is feasible. ${ }^{2}{ }^{3}$ This article describes the use of regular short dialysis treatment: the results suggest that it has a useful role in the current therapeutic crisis.

\section{Patients and Methods}

All patients receiving treatment in our renal unit during the period of the study were dialysed thrice weekly and maintained on a low potassium, $60-\mathrm{g}$ protein diet with fluid intake related to urine volume. Aluminium hydroxide was given to lower serum phosphate levels.

\section{ienal Unit, Royal Infirmary, Sunderland}

A. M. MARTIN, M.B., F.R.c.P., Consultant Physician A. ODURO-DOMINAH, M.B., Senior House Officer J. K. GIBBINS, R.M.N., S.R.N., Renal Unit Sister D. DEVAPAL, M.B., Medical Registrar D. C. MITCHELL, B.SC., Bioengineer
We compared the results of dialysis using $1-\mathrm{m}^{2}$ surface area devices for 6-9 hours with dialysis using $1 \cdot 5-\mathrm{m}^{2}$ devices for $3-3 \frac{1}{2}$ hours. Between 1970 and October 1973 dialysis was performed for nine hours using $1-\mathrm{m}^{2}$, non-disposable, flat-bed devices. From November 1973 until April 1974 several patients were treated with disposable $1-\mathrm{m}^{2}$ area-coil and hollow-fibre dialysers for a dialysis time of six

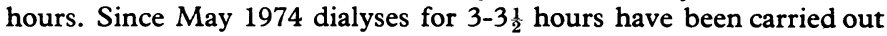
with a $1 \cdot 5-\mathrm{m}^{2}$ surface area coil (Ultraflo 2 Travenol) in a recirculation pot with a fluid addition rate of $500 \mathrm{ml} / \mathrm{min}$. Patients with Cimino Brescia fistulae were cannulated with 14-gauge butterfly needles (Abbot) and a blood flow rate of $250-300 \mathrm{ml} / \mathrm{min}$ was maintained with a roller pump. Heparinization was by continuous infusion during long dialyses and by a single injection on short dialysis. Pre- and postdialysis blood urea, creatinine, phosphate, and potassium levels were assessed by autoanalyser. Haemoglobin was determined by Coulter counter. Ultrafiltration was assessed by body weight change throughout dialysis. Dialyses were continued for $3 \frac{1}{2}$ hours when sufficient ultrafiltration was not achieved in three hours.

The results of short dialysis have been assessed in 23 patients over 143 patient months. In 16 patients the effects of treatment on a long and short dialysis schedule could be compared. The remainder were dialysed on the $1.5-\mathrm{m}^{2}$ coil device immediately. There were no adverse effects. The costs of the long, non-disposable dialysis and of the short disposable regimen have also been compared.

\section{Results}

In a total of 1800 short dialyses the overall rate of coil bursts was $1.5 \%$, of which $60 \%$ were during air tests.

\section{costs}

The effect of the short dialysis regimen on staffing, dialysis unit running hours, and dialysis costs are shown in table I. The items assessed under the cost of non-disposable dialysis were cuprophan membranes, arterial and venous lines, formalin sterilizing fluid, isotonic saline rinsing fluid, heparin infusion, and standby disposable

TABLE I-Logistics and Economics of Different Dialysis Regimens

\begin{tabular}{|c|c|c|c|c|c|c|}
\hline Period & $\begin{array}{c}\text { No. of } \\
\text { Patients } \\
\text { (Average) }\end{array}$ & $\begin{array}{c}\text { Dialysers } \\
\text { Used* }\end{array}$ & $\begin{array}{l}\text { Dialyses/ } \\
\text { Month }\end{array}$ & $\begin{array}{l}\text { No. } \\
\text { of } \\
\text { Staff } \dagger\end{array}$ & $\begin{array}{l}\text { Renal Unit } \\
\text { Use } \\
\text { (h/month) }\end{array}$ & $\begin{array}{c}\text { Cost } / \\
\text { Dialysis } \\
(£)\end{array}$ \\
\hline $\begin{array}{l}\text { November 1970- } \\
\text { October } 1973 \\
\text { November 1973- } \\
\text { April 1974 } \\
\text { May 1974 } \\
\text { April 1975 }\end{array}$ & $\begin{array}{l}19 \\
23 \\
25\end{array}$ & $\begin{array}{l}\text { N.D. } \\
\text { N.D. and D } \\
\text { d }\end{array}$ & $\begin{array}{l}238 \\
280 \\
310\end{array}$ & $\begin{array}{rl}16 & \mathrm{~N} \\
3 \mathrm{~T} \\
11 \mathrm{~N} \\
2 \mathrm{~T} \\
9 \mathrm{~N} \\
2 \mathrm{~T}\end{array}$ & $\begin{array}{l}456 \\
456 \\
240\end{array}$ & $\begin{array}{c}7 \\
\text { Not } \\
\text { assessed } \\
12 \cdot 25\end{array}$ \\
\hline
\end{tabular}
*N.D. = non-disposable; $\mathrm{D}=$ disposable (long); $\mathrm{d}=$ disposable (short). 
dialysers used in the event of non-disposable device rupture, and those assessed for short disposable dialysis were coil dialysers, arterial and venous lines, isotonic saline rinsing fluid, and heparin.

No account was taken of electricity running costs or the initial capital expenditure on non-disposable dialysers and coil recirculating pots. The sum of $£ 12.25$ in table I is the cost per dialysis of a group of patients treated solely on the short dialysis regimen and may be compared with the cost of $£ 7$ for a non-disposable dialysis. Nursing and technical staff salaries were not included in the costings. The theoretical reduction for short dialysis amounted to $42 \%$. The renal unit running hours were reduced from 456 to 240 per month with a concomitant reduction in unit nursing and technical staff from 19 to 11. Despite this it was possible to increase the number of dialyses from 238 to 310 per month. The introduction of short treatment times therefore increased productivity. A further $23 \%$ increase in dialyses per month was still possible with the current staff complement and unit running hours.

\section{EFFICACY OF TREATMENT}

Of the 16 patients who had both types of dialysis 14 had a creatinine clearance of $1 \mathrm{ml} / \mathrm{min}$ or less, two had clearances of $3-5 \mathrm{ml} / \mathrm{min}$, eight were anuric, and eight excreted 100-2000 ml of urine/24 h. Serum potassium levels, packed cell volume, post-dialysis weight loss, and blood pressure control were similar on the two regimens.

The mean concentrations of blood urea, creatinine, and phosphate in 16 patients before and after nine long and before and after nine short dialyses are shown in table II. Levels both before and after dialysis were increased in patients on the short treatment, but they were not associated with any symptomatic deterioration and they remained stable in well patients. Two patients, however, developed a respiratory infection with pneumonic signs and complicated by pericarditis. A viral aetiology was excluded and a diagnosis of "uraemic" pericarditis made. Both patients underwent successful pericardectomy. These patients had been maintained on short dialysis for three and four months respectively. Before that they had been on long dialysis for four years. During their acute illness the pre-dialysis blood urea and uric acid levels rose in one patient from $33.69 \mathrm{mmol} / 1$ $(203 \mathrm{mg} / 100 \mathrm{ml})$ to $44.15 \mathrm{mmol} / 1(266 \mathrm{mg} / 100 \mathrm{ml})$ and from 0.76 $\mathrm{mmol} / \mathrm{l}(12.8 \mathrm{mg} / 100 \mathrm{ml})$ to $1.24 \mathrm{mmol} / 1(21 \mathrm{mg} / 100 \mathrm{ml})$ respectively, and in the other patient from $31.20 \mathrm{mmol} / 1(188 \mathrm{mg} / 100 \mathrm{ml})$ to $37 \cdot 84 \mathrm{mmol} / 1(228 \mathrm{mg} / 100 \mathrm{ml})$ and from $0.54 \mathrm{mmol} / 1(9 \cdot 2 \mathrm{mg} / 100 \mathrm{ml})$ to $1.13 \mathrm{mmol} / 1(19 \mathrm{mg} / 100 \mathrm{ml})$ respectively.

TABLE II-Mean ( \pm S.D.) Concentrations of Blood Urea, Creatinine, and Phosphate Before and After Dialyses in 16 Patients

\begin{tabular}{|c|c|c|c|c|c|c|}
\hline \multirow[b]{2}{*}{ Dialysis } & \multicolumn{2}{|c|}{ Urea $(\mathrm{mmol} / \mathrm{l})$} & \multicolumn{2}{|c|}{ Creatinine $(\mu \mathrm{mol} / \mathrm{l})$} & \multicolumn{2}{|c|}{ Phosphate (mmol/l) } \\
\hline & Before & After & Before & After & Before & After \\
\hline Long & $25 \cdot 7 \pm 4 \cdot 2$ & $10 \cdot 1 \pm 2 \cdot 3$ & $1123 \pm 186$ & $548 \pm 150$ & $2 \cdot 1 \pm 0 \cdot 4$ & $1 \cdot 2 \pm 0.4$ \\
\hline Short & $30 \cdot 5 \pm 5 \cdot 4$ & $13.9 \pm 4 \cdot 2$ & $1264 \pm 221$ & $583 \pm 133$ & $2.5 \pm 0.5$ & $1 \cdot 1 \pm 0 \cdot 3$ \\
\hline
\end{tabular}

\section{SIDE EFFECTS}

The incidence of muscle cramps, nausea, vomiting, and symptomatic volume depletion in long and in short dialysis in 16 patients were compared. Muscle cramps were fewer on short dialysis. Symptomatic volume depletion occurred equally often in both long and short dialysis. There was a slight increase in the incidence of nausea and vomiting during short dialysis. Nine of the 16 patients developed dialysis symptoms more often during long than short dialysis.

\section{Discussion}

There is no satisfactory definition of adequate dialysis other than that it should prevent uraemic complications and rehabilitate the patient. The frequency and duration of dialysis varies from centre to centre according to the dialysers used and the manufacturers recommendations, the facilities available, and the nephrologist's opinion of what is needed. For $1-\mathrm{m}^{2}$ surface area dialysers this ranges from 2-3 times weekly for periods of 16-30 hours.

There have been two developments in relation to defining adequacy of dialysis. Firstly, Cambi et al. ${ }^{2}{ }^{3}$ have recently shown that the dialysis time may be reduced by using large surface area devices, avoiding biochemical disequilibrium, and utilizing centre dialysis stations more intensively. These reports stimulated the present study. The second development has been the concern over dialysing out middle-sized, unnamed uraemic molecules (molecular weight $>1000$ ).${ }^{4}$ The significance of these is still uncertain, and attempts to remove them by means of non-cellulose membranes ${ }^{5}$ are at present proving too costly.

Our study shows the advantages of short, thrice weekly dialyses with a $1 \cdot 5-\mathrm{m}^{2}$ surface area dialyser. Water and blood pressure control was adequate and the incidence of infectious illness did not increase during the period of study. There was poorer control of blood urea, creatinine, and phosphate levels compared to that with "standard" dialysis procedure, and that may be relevant to the two cases of pericarditis. Both patients were chronic bronchitics who developed pneumonia, and the onset of uraemic pericarditis might indicate some inadequacy of biochemical control during periods of increased catabolism. Nevertheless, pericarditis also occurs with long dialysis regimens and its aetiology is ill-defined.

The increase in pre-dialysis phosphate levels with short treatment times emphasizes a need to give aluminium hydroxide more regularly. Over the period there was no significant change in the serum alkaline phosphatase levels. The duration of the study was too short to come to conclusions on bone status.

The economics of the unit and the results of treatment benefitted from using shorter dialysis times. Many patients spontaneously reported feeling less "washed out" and able to function for seven days a week rather than only three with long treatments. A shorter dialysis time has enabled the unit work load to increase despite a reduction in trained nursing and technical staff. Staff shortage is a national problem owing partly to the technical nature of the nursing duties and partly to the existence of chronic, low-grade anxieties and hostilities between patients and staff. ${ }^{6}$ Shorter treatment times could reduce these frictions.

\section{References}

1 Pendreigh, D. M., et al., Lancet, 1972, 1, 304.

2 Cambi, V., et al., Proceedings of European Dialysis and Transplant Association, vol. 10, p. 271. London, Pitman Medical, 1973.

${ }^{3}$ Cambi, V., et al., Proceedings of European Dialysis and Transplant Association, vol. 10, p. 342. London, Pitman Medical, 1973.

4 Babb, A. L., et al., Transactions American Society for Artificial Internal Organs, 1971, 17, 81.

${ }^{5}$ Man, N. K., et al., Proceedings of European Dialysis and Transplant Association, vol. 10, p. 236. London, Pitman Medical, 1973.

6 Daly, R. J., Fournal of Psychosomatic Research, 1969, 13, 265.

7 Halper, I. S., Medical Clinics of North America, 1971, 55, 177. 